THURSDAY, OCTOBER 28, 19 I5.

THE UNIVERSITIES AND WAR ECONOMY. UCH anxiety has been caused in the educaI tional world by the circular of date July 28 from the Lords Commissioners of the Treasury to those universities and similar institutions in Great Britain which are in receipt of Government grants. In consequence partly of this circular, and partly of the general need for economy in the expenditure of public funds, a letter of date August 26 has been addressed to the joint secretaries of the Committee on Public Retrenchment by the Vice-Chancellors of the four northern universities (Leeds, Liverpool, Manchester, and Sheffield).

The danger which threatens our universities is the more imminent because the Treasury circular appears to take a quite reasonable view of the situation. In consequence of the loss of students due to their enlistment, the colleges have suffered from a serious reduction both in the size of the classes and in the income received from fees. To compensate for the latter loss special supplementary grants were given to them last year. It is pointed out by the Treasury authorities that if these special grants are to be continued throughout the war, however prolonged, and all the institutions so aided are to be allowed to remain open, however low the attendance of students may be, the burden on public funds-which would increase progressively as young men continue to enlist-might prove ultimately to be very great and out of all proportion to the educational benefits conferred on the community. Acting on this assumption, the circular foreshadows a possible very considerable reduction in the amount which Parliament is to be asked to vote in the future. It is suggested that savings might be effected not only by leaving all vacancies unfilled (we understand that the University of London is to remain without a Principal on this account), but also by temporary suspension of institutions, classes, departments, or hostels where the attendance falls below a certain level, the staff thus released being provided with suitably remunerated work of some other kind more directly useful in the present emergency. The colleges are also asked to submit an estimate of their probable expenditure and revenue, and to point out the directions in which they are able to effect further savings.

If the efficiency of universities could be measured by the number of students that they turn out, there might be a valid justification for the opinions No. 2400 , VOL. 96] expressed in the Treasury circular. But the war by which Germany now seeks to cripple Great Britain, and the successful war which Germany has been waging against our commerce for the last quarter of a century without opposition, have placed on our Universities a burden of national responsibility which cannot be measured by mere numbers of students. There has probably been no period in the history of our country when so great a demand existed for enterprise and activity in our universities as during the present national crisis.

The letter of the northern universities affords a conclusive reply to the Treasury circular. It is accompanied by a statement of the active work which the colleges have undertaken in connection with the war. This statement is of a confidential character, but it may here be safely stated without any risk of assisting the enemy that it includes practically every branch of pure and applied science. In addition statistics are given as to the numbers of staff and students serving with the colours or engaged in munition work.

It used to be said that England's battles were won on the playgrounds of the great public schools, and it is still true that these are largely responsible for the magnificent performance of our men in the trenches. But it is equally true that Germany's war against the allied European Powers has been waged in the laboratories of the German universities. It is now being recognised that this is a war of brains and science. It is sufficiently unfortunate if the supply of scientifically trained students be reduced at the present juncture, but it will be still more unfortunate if a check is placed on their future activities, which would probably have a permanent and cumulative effect on our national development. If England is to win this war, England must also be prepared to maintain a struggle for power, which will certainly not cease with the conclusion of hostilities. We have heard much talk about "silver bullets," but Germany's silver bullets have to a large extent been supplied by Great Britain in exchange for chemical and optical goods and dyestuffs.

The contingents of the Officers Training Corps of the northern universities have already contributed more than 1000 officers to the Forces, and similar contingents have been furnished by other modern universities. It has been abundantly shown by the statements received from past students that they have found their university training of the greatest possible value in the field. There can be no better preparation for the $\mathrm{K}$ 
exigencies of modern warfare than a first-year course in physics, chemistry, and mathematics, varied in some cases by medical and biological studies, and if this course can be followed by a second-year course including physical applications of the infinitesimal calculus, so much the better. It is true that we have military colleges, but the instruction in these would appear to be carried on by rule-of-thumb methods to a greater extent than in our universities, and therefore less calculated to produce the type of individual who can think and act in an emergency.

But all modern university colleges are largely attended by women, and with a growing demand for women's work in posts hitherto occupied by men, some increase in the numbers of these students may be anticipated. In any case, it would be a fatal misfortune if anything were done which could in any way interfere with this side of the university work.

Even if our colleges were entirely depleted of their students, there would still be grave objections to a proposal for disestablishing and disendowing them. The claims of the professor who lectures only six or eight hours a week and devotes the rest of his time to research are very well put forward by Prof. Grant Showerman in the Popular Science Monthly for June, 1915, in an article entitled "The Liberal Arts and Scientific Management." A professor may receive fourteen dollars for every hour that he is down to lecture in the time-table, but it is pointed out that his connection with his work never ceases throughout the day or the year, and when this is taken into account his princely salary reduces to about $\mathrm{r.2}$ dollars per hour for expert service in a profession requiring unusually protracted preparation and involving social relations with the best paid classes of the community.

As soon as lectures are over, the average professor devotes his attention to research, and not only does he receive no remuneration for this work, but he frequently pays the cost of apparatus or publishes books at his own expense. Not only in the northern universities, but also in nearly every other university in the kingdom, laboratories and college staffs have been generously placed at the disposal of the Government. While the nation is paying high wages for unskilled labour, it is not only paying nothing for assistance the value of which may be reckoned in millions, but it is even receiving income tax and other dues from the donors at a rate calculated in many cases to place considerable anxiety on their shoulders.

The reason why the college professor engages in research, even at the risk of stinting himself and family in the necessities of life, is that he cannot help himself. $\mathrm{He}$ has an object to perform, and his happiness depends mainly on its accomplishment. It is certain that a falling off, should such occur, in the amount of class work would lead to an increased amount of research at a time when that research is urgently needed by the Government-more urgently needed than the Government or any similar body can possibly appreciate. Not only are mathematics, physics, and chemistry needed in connection with such varied applications as aeroplanes, wireless telegraphy, poisonous gases, periscopes, and explosives, but entomology, leather-making, economics, modern languages, botany, law, and history all have their uses in connection with the war.

The suggestion that certain members of the college staffs should be released and that they should be asked to find temporary paid work elsewhere, is one that ought only to be carried out with extreme caution. At the present time many professors and lecturers have undertaken temporary military or other duties, and the colleges are already effecting savings by the amounts of the salaries thus set free. It would thus appear that the system has already been adopted on a voluntary basis by the college staffs themselves. It is not evident from the circular whether, and if so how far, the Treasury contemplates the possibility of exercising pressure in the same direction, but we should be sorry to think that it has any desire to do so. Such an attempt would necessarily involve one of two alternatives, either "putting a round man into a square hole"-in which case good-bye to all the usefulness of his work, perhaps an irreparable loss to the community-or payment for research.

Now it would undoubtedly be of great advantage that persons engaged in valuable investigations should receive some compensation for the loss of income they may incur in carrying on the work. But it would be quite impossible for any Government at the present time to carry through any scheme which Labour leaders would distort into a proposal to put money into the pockets of the "idle rich." Even if this difficulty were overcome, payment for research would be sure to be made conditional on a clear statement being made as to the results aimed at and the practical uses to which they were to be applied. Now the main essence of research is that something has to be found out, the result of which is unknown, and it cannot be possibly anticipated at the outset what practical applications may arise. Any 
attempt to place this work under a system of Government control and inspection would involve the exclusion of the important class of investigations which leads to the most novel and farreaching results.

Our universities are straining their resources to the utmost in the effort to keep down expenditure. Where members of their staffs have gone on active service (in some departments to the extent of above fifty per cent.) their work is being cheerfully taken over by their colleagues. Not only are building operations being suspended (and this is probably a wise precaution for many reasons), but the purchase of books and apparatus is being reduced to the bare minimum.

The extra work undertaken by the remaining members of the staffs is only reduced in a very slight degree by the falling off in students. So long as a certain number of classes have to be held, a difference in the numbers of each class does not make a great difference in the work. The strain is bound to make itself felt sooner or later. But there are noticeable cases in which the effort to secure economy appears to have been carried too far. It cannot be desirable in the public interest that vacancies in two such important departments as physics and chemistry should remain unfilled, and we believe that it is in the interests of the Government, instead of bringing pressure on the universities to effect further economies, rather to exert its influence in checking them from going too far.

The four Vice-Chancellors of the northern universities are to be congratulated on the strong case they have made out. The matter is, however, one which affects all the modern institutions of university rank, and several of the statements in this article have been derived from independent sources. We hope that the action which is now being taken will prevent a mistake being made which must inevitably lead, sooner or later, to the realisation of the ideals of German militarism at the expense of Great Britain.

\section{OLD-FASHIONED NATURAL HISTORY} AND NEW-FASHIONED BOTANY.

(1) The Hundred Best Animals. By Lilian Gask. Pp. 304. (London: G. G. Harrap and Co., 1914.) Price 7s. 6d. net.

(2) True Stories about Horses. By Lilian Gask. Pp. 266. (London: G. G. Harrap and Co., n.d.) Price $3 s .6 d$. net.

$$
\text { NO. } 2400 \text {, YOL. 96] }
$$

(3) The FIuman Side of Plants. By Royal Dixon. Pp. $x i x+201$. (London: Grant Richards, Ltd., I9I5.) Price $7 s .6 d$. net.

(r) THE stories of a hundred animals of dis1 tinction are told to two children by a veteran who had been a mighty hunter in his day, and good stories they are. $\mathrm{He}$ talked mostly about mammals-lion and tiger, seal and walrus, elephant and ape, camel and llama, antelope and deer, sloth and ant-eater, kangaroo and duckbill. But, like Solomon, the veteran spake also, in the last five of the twenty-nine chapters, "of fowl, and of creeping things, and of fishes." We are not sure that Solomon would always have agreed with him; for instance, about the water reservoirs in the camel's stomach; or as to the advisability of telling children that wise folk think the tallest animal in the world has lengthened out its neck by so much reaching; or that "squirts out" is the right word to use in regard to the exudation of toad's poison. But there is no doubt that the book is one which children will thoroughly enjoy and also profit by.

The talks are natural, interesting, instructive, with fresh news to tell, and with no tiresome "writing down." Just now and again the old Nimrod nods a little; for instance, on the last page when he says, in a way quite unlike himself: "We come to understand the highest examples of the different animals-call them best if you will-by comparing them with others of the same species below them in the scale, whether of physical strength and beauty or intelligence." $\mathrm{He}$ was also nodding when he said that the heron "is very scare in England now." But these are trivial matters; the important fact is that this is a thoroughly sound and successful book to be cordially recommended. It is adorned and illumined by a hundred excellent illustrations-often strikingly alive-from original photographs by A. F. W. Vogt.

(2) The second book from the same pen is also intended for young readers. It contains many well-told true stories about horses. We are told of the doctor's horse that defended its sleeping master; of the horse that fought and defeated the wolves it had been left to satiate; of an Arabian horse that twice saved a soldier's life; of a number of mares, some past foaling, which combined for six hours to lift the foals above the level of a flood; of a Shetland pony that saved a child from drowning; of a horse that kept a long vigil over a dead soldier; of another that lifted a little child out of harm's way, and of many more besides. As will be seen from the examples cited, the stories are of a homely, old-fashioned type, and we 